\title{
Biosafety of Nanoparticles Used in Orthodontics - A Literature Review
}

\author{
Nausheen Mobeen ${ }^{1}$, Shreya Kishore ${ }^{2}$, Rasiga Gandhi ${ }^{3}$ Sangeetha Duraisamy ${ }^{4}$, Ravi K. ${ }^{5}$ \\ 1, 2, 3, 4, 5 Department of Orthodontics and Dentofacial Orthopaedics, \\ SRM Dental College, Ramapuram, Chennai, Tamil Nadu, India.
}

\section{ABSTRACT}

Nanotechnology is the science of manipulating matter, measured in the billionths of a nanometer, roughly the size of two or three atoms. It is widely used in our day-today life including its use in medicine and is considered as a vital current technology of the $21^{\text {st }}$ century based on its economic and scientific potential. Its application is being experimented in various domains in orthodontics, from surface coatings to the development of novel materials. Orthodontic materials must have specific characteristics such as biological safety, functionality, and adequate tissue response. They have to pass specific biocompatibility tests to meet regulatory standards. Any material used in oral cavity might encourage unnecessary disturbance due to its complex and varied environment. The nanomaterials have many advantages in the field of orthodontics, especially with improved mechanical and antimicrobial properties. Nanoparticles can easily penetrate tissues and can affect biological behaviours at different levels. The introduction of nanotechnology gives better opportunities to both patient and orthodontist to new physicochemical, mechanical, and antibacterial properties of nanosized materials and can be used in coating orthodontic wires, elastomeric ligatures, and brackets, producing shape memory polymers and orthodontic bonding materials. The present review article focuses on the application of nanoparticles in orthodontics. This article presents a brief overview of nanotechnology, types of nanoparticles, biological safety of different nanoparticles used in orthodontics and their applications in the field of dentistry and orthodontics.

\section{KEY WORDS}

Nanoparticles, Biocompatibility, Orthodontics, Nanoscience
Corresponding Author: Dr. Nausheen Mobeen, Department of Orthodontics and Dentofacial Orthopaedics, SRM Dental College, Ramapuram, Chennai, Tamil Nadu, India. E-mail: nausheenmobeen@gmail.com

DOI: $10.14260 / j e m d s / 2021 / 543$

How to Cite This Article: Mobeen N, Kishore S, Gandhi R, et al. Biosafety of nanoparticles used in orthodontics - a literature review. J Evolution Med Dent Sci 2021;10(32):26582664, DOI: $10.14260 /$ jemds/2021/543

Submission 09-05-2021,

Peer Review 05-07-2021,

Acceptance 11-07-2021,

Published 09-08-2021.

Copyright (c) 2021 Nausheen Mobeen et al. This is an open access article distributed under Creative Commons Attribution License [Attribution 4.0 International (CC BY 4.0)] 


\section{BACKGROUND}

Nanotechnology is defined as "the direct manipulation of materials at the nanoscale" 1 and one of the most prominent areas for current research and development across a wide range of fields. ${ }^{2}$ Prof. Kerie E. Drexeler coined the term "nanotechnology" in his book "Engines of Creation" in 1986, and Norio Taniguchi, a researcher, defined it as "the processing, separation, integration, and deformation of materials by one atom or one molecule."

Nanoscience involves the study of materials on the nano scale level between approximately 1 and $100 \mathrm{~nm}$. These materials have been receiving considerable attention as a result of their unique physical and chemical properties, biological properties, and functionality due to their nano scale size, and have elicited much interest and important applications in optics and biomedicine. ${ }^{4}$ Nanoparticle presents a greater surface - to - volume ratio when compared with non - nano scale particles, interacting more closely with microbial membranes and provides considerably larger surface area for antimicrobial activity. ${ }^{5}$ There are two ways to produce nanomaterials ${ }^{3}$

1. Top - down approach: It starts with bulk material and then breaks it into smaller pieces using mechanical, chemical or other forms of energy.

2. Bottom - up approach: It synthesizes the material from atomic or molecular species via chemical reactions, allowing for the precursor particles to grow in size.

Nanoparticles are generally classified based on different shapes of nanoparticles such as rod, rectangle, hexagon, cube, triangle, and star - shaped nanoparticles can be produced. Bulk solution synthetic methods often produce nanoparticles of multiple sizes and shapes and low yield of the desired size and shape. ${ }^{3}$ In the field of dentistry, orthodontic material must have specific characteristics such as biological safety and functionality, adequate tissue response and resistance to corrosion and metals used are also identified to be cytotoxic, mutagenic and allergenic to oral tissue. Biosafety of nanoparticle materials is a subject of concern, the future in orthodontic treatment will benefit enormously through nanotechnology and its clinical application are at a reasonable cost to the orthodontist and the patients. ${ }^{2}$

This paper intends to give an extensive understanding of the biological safety of nanoparticles and their use in orthodontics and discuss the new application of nanoparticles in orthodontics with the present research evidence.

\section{FACTORS AFFECTING THE BIOSAFETY OF NANOPARTICLES}

Medical nanoparticles as three main categories $^{6}$ soft; hard solid; and other.

a. Soft particles, such as polymer NPs, micelles, vesicles, liposomes, core - shell systems, gels, polymeric medicines, or polymer - drug conjugates, typically made up of polymers, proteins, or lipids.

b. Metal and ceramic nanoparticles, such as oxides, semiconductors, and carbon nanotubes, as well as nanocrystal medicinal formulations, are examples of hard solid - core nanoparticles. c. Due to their nano size and structure, other particles in the third category, such as antibody drug conjugates and albumin particles, can also facilitate nano type interactions.

The nanometer size of the nanomaterials renders them

a) A large fraction of surface atoms;

b) High surface energy;

c) Spatial confinement; and

d) Reduced imperfections,

Which normally do not exist in the corresponding bulk material. At the nanometer scale, properties become size dependent, which include

1. Chemical properties - reactivity, catalysis;

2. Thermal properties - melting temperature;

3. Mechanical properties - adhesion, capillary forces;

4. Optical properties - absorption and scattering of light;

5. Electrical properties - tunnelling current; and

6. Magnetic properties - superparamagnetic effect. ${ }^{7}$

The nanoparticles' enormous surface - to - volume ratio is a major factor in their new physical, chemical, and mechanical capabilities as compared to the bulk state. As particle size fall results in nanoparticles having a substantially bigger surface area per unit volume than bigger particles. This makes nanoparticles more chemically reactive than a similar mass of material made up of bigger particles. ${ }^{8}$

\section{APPLICATION OF NANOPARTICLES IN DENTISTRY \& ORTHODONTICS}

Nanoparticles are being investigated to inhibit the formation of biofilms in the oral cavity due to their biocidal, antiadhesive and transport characteristic. Various metal-based nanoparticles known for their size and exceptional properties and therapeutic uses in dentistry and orthodontics are discussed in Table 2.

Various metal-based nanoparticles are -

a) Gold nanoparticles

b) Silver nanoparticles

c) Titanium - based nanoparticles

d) Fullerene nanoparticles

e) Chitosan nanoparticles

f) Fluoride releasing nanoparticles

g) Hydroxyapatite nanoparticles

h) Zinc nanoparticles

i) Copper nanoparticles

j) Magnesium nanoparticles

k) Quaternary Ammonia Nanoparticles

Original research on novel nanoparticles in orthodontics, both in-vitro and in-vivo, was identified and extracted from Medline via PubMed, Google Scholar, and Scopus from 2010 to 2020 (Table 1)

These metal-based nanoparticles are coated on orthodontic material and employed as nano - adhesives for bonding orthodontic appliances, with filler - particle sizes of less than $100 \mathrm{~nm}$. These nanocomposites are made through flame pyrolysis, which involves incorporating nano - sized fillers into composites. ${ }^{4}$ Nanoparticles are inserted into orthodontic arch wires in an electroless method to create nanocoated arch wires. 


\begin{tabular}{|c|c|c|c|c|}
\hline Sl. No & Author & Study Design & Characteristic & Outcome \\
\hline 1. & $\begin{array}{l}\text { Mohamed K - Al Nafori } \\
\text { et al. in the year } \\
2017^{16}\end{array}$ & $\begin{array}{l}\text { Original } \\
\text { Research article- } \\
\text { animal study }\end{array}$ & $\begin{array}{l}\text { Incorporated gold and silver nanoparticles into the primer of orthodontic } \\
\text { adhesive system and coated the brackets on the sheep teeth. }\end{array}$ & $\begin{array}{l}\text { Incorporating Au and Ag nanoparticles did not affect the bond strength } \\
\text { or the primer ability to wet enamel surface. }\end{array}$ \\
\hline 2. & $\begin{array}{l}\text { Gamze Metin - Gürsoy } \\
\text { et al. in the year } \\
2016^{41}\end{array}$ & In vivo study & $\begin{array}{l}\text { Used nano - silver coated orthodontics brackets in contact or placed near } \\
\text { the gingiva or oral epithelium. }\end{array}$ & $\begin{array}{l}\text { It was found to have better tissue compatibility features compared to the } \\
\text { standard type orthodontic bracket. }\end{array}$ \\
\hline 3. & $\begin{array}{l}\text { Gamze Metin - Gürsoy } \\
\text { et al. in } 2017^{40}\end{array}$ & In vivo study & $\begin{array}{l}\text { Used nano - silver coated orthodontic brackets on the teeth to check the } \\
\text { antibacterial properties. }\end{array}$ & $\begin{array}{l}\text { Nano - coated orthodontic bracket is effective in the inhibition of } S \text {. } \\
\text { mutans and reduction in smooth surfacecaries. }\end{array}$ \\
\hline 4. & $\begin{array}{l}\text { Mhaske et al. in the } \\
\text { year } 2015^{42}\end{array}$ & In vitro study & $\begin{array}{l}\text { To accesses the antiadherent and antibacterial properties of against } \\
\text { Lactobacillus acidophilus. }\end{array}$ & $\begin{array}{c}\text { Nano - silver coated orthodontic wire can be used to prevent the } \\
\text { development of dental plaque and dental caries during orthodontic } \\
\text { treatment }\end{array}$ \\
\hline 5. & $\begin{array}{l}\text { Priyanka K. Shah et al. } \\
\text { in the year } 2018^{19}\end{array}$ & In vitro study & $\begin{array}{c}\text { Compared the frictional properties between silver coated SS wire and } \\
\text { uncoated SS wire }\end{array}$ & $\begin{array}{l}\text { The study confirmed improvement in frictional properties of } \\
\text { arch wires by modifying the surface. }\end{array}$ \\
\hline 6. & $\begin{array}{l}\text { Alma E. Hernández - } \\
\text { Gómora et al. in the } \\
\text { year } 2017^{43}\end{array}$ & In vitro study & $\begin{array}{l}\text { Silver nanoparticles were synthesized in situ on orthodontic elastomeric } \\
\text { modules (OEM) using silver nitrate salts }\end{array}$ & $\begin{array}{l}\text { Orthodontic elastic modules decorated with AgNPs demonstrated higher } \\
\text { physical properties such as maximum strength, tension and } \\
\text { displacement compared to conventional module }\end{array}$ \\
\hline 7. & $\begin{array}{l}\text { Adith Venugopal et al. } \\
\text { in } 2017^{44}\end{array}$ & In vitro study & $\begin{array}{l}\text { Prepared two different titanium alloy: one coated with regular AgNPs (Ti - } \\
\text { AgNP) and the other coated with titanium biopolymer - AgNP(Ti - BP - } \\
\text { AgNP) }\end{array}$ & $\begin{array}{l}\text { The Ti - BP - AgNP surface showed clear zone of inhibition and had } \\
\text { remarkable antibacterial activity towards the oral bacteria S. mutans, } S \text {. } \\
\text { sangunis and A. actinomycetemcomitans. }\end{array}$ \\
\hline 8. & $\begin{array}{l}\text { Danna Mota Moreira } \\
\quad \text { et al. } .^{18} \text { in } 2018\end{array}$ & In vitro study & $\begin{array}{l}\text { Introduced novel antimicrobial orthodontic band cement with in situ- } \\
\text { generated Agnps. }\end{array}$ & $\begin{array}{l}\text { These resins have comparable mechanical properties to the } \\
\text { control group and sustained Ag+ ion release, significant } \\
\text { bacterial inhibition and excellent biocompatibility. }\end{array}$ \\
\hline 9. & $\begin{array}{l}\text { Baocheng CAO et al. }{ }^{22} \\
\text { in } 2013\end{array}$ & In vitro study & $\begin{array}{l}\text { Orthodontic brackets coated with a thin film of nitrogen - doped TiO2 NPs } \\
\text { particle size } 33 \mathrm{~nm}\end{array}$ & $\begin{array}{l}\text { The bracket coated with the TiO2 - xNy thin film shows high } \\
\text { antimicrobial activity against } S \text {. mutans, } L \text {. acidophilus, A. viscous, and } C \text {. } \\
\text { albicans. The coated bracket was effective in prevention of enamel } \\
\text { demineralization and gingivitis during orthodontic treatment. }\end{array}$ \\
\hline 10. & $\begin{array}{l}\text { Maryam Poosti et al. }{ }^{45} \\
\text { in } 2013\end{array}$ & In vitro study & $\begin{array}{l}\text { The light cure orthodontic composite containing } 1 \%(\mathrm{w} / \mathrm{w}) \mathrm{TiO} 2 \\
\text { nanoparticles was quite effective in inhibiting bacterial growth }\end{array}$ & $\begin{array}{l}\text { Adding TiO2 nanoparticles to orthodontic composite enhances its } \\
\text { antibacterial effects without compromising the physical properties } \\
\text { (shear bond strength) }\end{array}$ \\
\hline 11. & $\begin{array}{l}\text { Daniela Dellosso et al. } \\
\quad{ }^{46} \text { in } 2017\end{array}$ & In vitro study & $\begin{array}{l}\text { The author suggested adding titanium oxide nanotubes have the potential } \\
\text { to improve GICs surface roughness and hardness and may reduce } \\
\text { biomechanical degradation of the material }\end{array}$ & 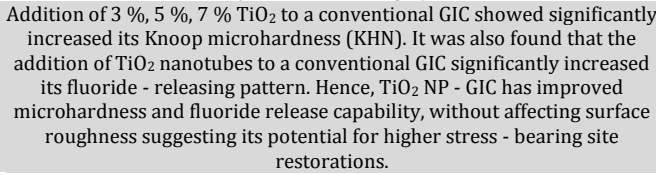 \\
\hline 12. & $\begin{array}{l}\text { Chia - Tze Kao et al. }{ }^{1} \\
\text { in } 2002\end{array}$ & In vitro study & $\begin{array}{l}\text { The plated metal bracket was produced by the titanium nitride (TiN) ion - } \\
\text { plating method. Both TiN - and non - TiN - plated brackets may release } \\
\text { detectable ions into the test solution, including nickel, chromium, } \\
\text { manganese, copper, and iron (ferric) were tested under atomic absorption } \\
\text { spectrophotometry and atomic emission spectrophotometry for anti - } \\
\text { corrosion properties. }\end{array}$ & $\begin{array}{l}\text { The TiN - plated metal bracket did not increase the anticorrosion ability } \\
\text { of the standard bracket. The biocompatibility of the TiN plating versus } \\
\text { the standard bracket material resulting from bracket immersion in the } \\
\text { test solution revealed no toxicity on human osteogenic sarcoma (U2OS } \\
\text { cells) }\end{array}$ \\
\hline 13. & $\begin{array}{l}\text { M. Redlich et al. }{ }^{25} \text { in } \\
\quad 2008\end{array}$ & In vitro study & $\begin{array}{r}\text { The SS wires coated with ni } \\
\text { WS }_{2} \text { nanoparticles. The properties } \\
\text { analysed by a }\end{array}$ & $\begin{array}{l}\text { The results displayed excellent friction and wear properties due to their } \\
\text { unique fullerene - like structure. The toxicity of the fullerene - like } \\
\text { nanoparticles have provided indications that they are biocompatible. }\end{array}$ \\
\hline 14. & $\begin{array}{l}\text { Friedman } \mathrm{H} \text { et al. }{ }^{24} \text { in } \\
\quad 2007\end{array}$ & In vitro study & $\begin{array}{l}\text { Cobalt films impregnated with IF - WS2 nanoparticles (Co + IF) were } \\
\text { successfully deposited by both electroless and electro - deposition } \\
\text { processes onto stainless steel substrates. The films were characterized by a } \\
\text { number of analytical techniques, which ascertained their morphology, } \\
\text { crystallinity and chemical composition. }\end{array}$ & $\begin{array}{l}\text { Nano - composite coatings show lower friction and wear as } \\
\text { compared to either the cobalt coating or the stainless-steel substrate } \\
\text { itself; however, better adhesion was observed for films obtained by } \\
\text { electroless deposition. }\end{array}$ \\
\hline 15. & $\begin{array}{l}\text { Mirhashemi A.H et al. } \\
{ }_{28} \text { in } 2013\end{array}$ & In vitro study & $\begin{array}{l}\text { Incorporated chitosan (CS) and zinc oxide (ZnO) nanoparticles (NPs), into } \\
\text { the composite and assessed antimicrobial properties. }\end{array}$ & $\begin{array}{c}\mathrm{ZnO} \text { - NPs and Chitosan NPs cause inhibition of bacterial biofilm, which is } \\
\text { more prominent with higher NP concentrations especially in } 10 \% \\
\text { weight concentrations. The } 5 \% \text { group significantly reduced S. mutans } \\
\text { and the } 10 \% \text { group inhibited S. sanguis and Streptococcus mutans and } \\
\text { Lactobacillus acidophilus significantly. }\end{array}$ \\
\hline 16. & $\begin{array}{l}\text { Sodagar. A et al. }{ }^{20} \text { in } \\
\qquad 2016\end{array}$ & In vitro study & $\begin{array}{l}\text { Incorporated nano - chitosan of different concentration } 1 \%, 3 \%, 5 \% \text { and } \\
10 \% \text { in the orthodontic composite and measured the shear bond strength } \\
\text { along with its antimicrobial properties. }\end{array}$ & $\begin{array}{l}\text { The bond strength is decreased as the percentage of chitosan } \\
\text { nanoparticles and the bacterial biofilm inhibition in composite } \\
\text { containing chitosan nanoparticles is significantly more than } \\
\text { conventional composite resins. According to the author, the use } \\
\text { of } 1 \% \text { weight of NP might be advisable with mechanical } \\
\text { modifications. }\end{array}$ \\
\hline 17. & $\begin{array}{l}\text { Mary A. S. Melo et al. } \\
\text { 30in } 2014\end{array}$ & In vitro study & $\begin{array}{l}\text { The author used four groups: non - fluoride - releasing microfilled } \\
\text { composite, fluoride - releasing microfilled composite, resin - modified glass } \\
\text { ionomer cement (RMGI), and fluoride - releasing nanofilled composite (FN). } \\
\text { He evaluated for fluoride releasing and enamel demineralization inhibition } \\
\text { capacity of fluoride - releasing nano filled cement around orthodontic } \\
\text { brackets using an artificial caries biofilm model }\end{array}$ & $\begin{array}{l}\text { Their studies have shown evidence that only RMGI was capable of } \\
\text { decreasing demineralization around orthodontic brackets and the } \\
\text { inclusion of nanofillers fluoridated composite resin did not provide } \\
\text { greater inhibition ofdemineralization. }\end{array}$ \\
\hline 18. & $\begin{array}{l}\text { Enan and Hammad }{ }^{31} \\
\text { in the year } 2013\end{array}$ & In vivo study & $\begin{array}{l}\text { Added nano - hydroxyapatite (Nano - HA) to conventional GIC used for } \\
\text { band cementation and measured the microleakage under orthodontic } \\
\text { bands, which was assessed by the methylene blue dye penetration method } \\
\text { after } 60 \text { days. }\end{array}$ & $\begin{array}{c}\text { GIC with } 15 \% \text { nano - HA is a promising material for orthodontic } \\
\text { banding that may guarantee a minimal amount of } \\
\text { demineralization around the bands at the end of orthodontic } \\
\text { treatment. }\end{array}$ \\
\hline 19. & Chung et al. ${ }^{32}$ in 2016 & In vitro study & $\begin{array}{l}\text { Prepared inorganic-organic nanocomposites by HA asinorganic component } \\
\text { of nanocomposites ( } 75 \% \mathrm{w} \text { ) and natural polymers (chitosan, alginate and } \\
\text { albumin) as organic components of nanocomposites }(25 \% \mathrm{w}) \text { and checked } \\
\text { for cytotoxicity using MTT assay test. }\end{array}$ & $\begin{array}{l}\text { The results showed no cytotoxicity in the MG - } 63 \text { cell line (human bone } \\
\text { osteosarcoma). HA nanoparticles were biocompatible. }\end{array}$ \\
\hline 20. & $\begin{array}{l}\text { Ramazanzadeh. B et al. } \\
34 \text { in the year } 2015\end{array}$ & In vitro study & $\begin{array}{l}\text { Used three groups: } \mathrm{ZnO} \text { nano - coated brackets, CuO nano - coated brackets } \\
\text { and combined ZnO - CuO nano - coated brackets. All these brackets were } \\
\text { subjected to antimicrobial test against } S \text {. mutans. }\end{array}$ & $\begin{array}{l}\text { It has been observed that } \mathrm{CuO} \text { and } \mathrm{ZnO} \text { - } \mathrm{CuO} \text { nanoparticles coated } \\
\text { brackets have better antimicrobial effect on S.mutans than brackets } \\
\text { coated with Zinc oxide or } \mathrm{CuO} \text { alone. }\end{array}$ \\
\hline 21. & $\begin{array}{l}\text { Behroozian et al. }{ }^{47} \text { in } \\
\text { the year } 2016\end{array}$ & In vitro study & $\begin{array}{c}\text { Deposited } \mathrm{ZnO} \text { nanoparticles on SS wire and measured friction } \\
\text { sliding the wire with an uncoated porcelain bracket }\end{array}$ & $\begin{array}{l}\text { The deposition of such nanoparticles significantly decreased the } \\
\text { frictional forces between the SS wire and porcelain brackets in } \\
\text { the sliding technique. The benefits are decreasing treatment } \\
\text { time and the risk of root resorption are potential advantages of } \\
\text { decreasing friction between brackets and wires. }\end{array}$ \\
\hline 22. & $\begin{array}{l}\text { Figueroa et al. }{ }^{37} \text { in the } \\
\text { year } 2015\end{array}$ & vitro study & $\begin{array}{l}\text { Incorporated Copper oxide nanoparticles to orthodontic adhesive at } 0.0100 \\
\text { wt } \%, 0.0075 \text { wt } \% \text {, and } 0.0050 \mathrm{wt} \% \text { and measured the bond strength. }\end{array}$ & $\begin{array}{l}\text { It was observed higher bond strength was obtained with the orthodontic } \\
\text { adhesive that included } 0.0100 \mathrm{wt} \% \text { of copper NPs }\end{array}$ \\
\hline 23. & $\begin{array}{l}\text { Toodehzaeim et al. }{ }^{38} \\
\text { in } 2018\end{array}$ & In vitro study & $\begin{array}{c}\text { Incorporated CuO nanoparticle into adhesive (Trans - bond XT adhesive 3M } \\
\text { Unitek, USA) in three concentrations } 0.01,0.5 \text { and } 1.0 \mathrm{wt} . \% \text { and assessed } \\
\text { the shear bond strength and antimicrobial properties. }\end{array}$ & $\begin{array}{l}\text { Incorporating CuO nanoparticles in all three concentrations has no } \\
\text { negative effect on shear bond strength of adhesive. These nanoparticles } \\
\text { probably can act as nano - fillers and enhance shear bond strength of } \\
\text { adhesive. And increasing concentration of copper oxide nanoparticles } \\
\text { does not increases the S.mutans inhibition zone }\end{array}$ \\
\hline 24. & $\begin{array}{l}\text { Imani. M et al. } .^{48} \text { in } \\
2019\end{array}$ & In vitro study & $\begin{array}{l}2019 \text { synthesed of magnesium oxide nanoparticles using the Taguchi } \\
\text { method. The size and morphology of the synthesized magnesium oxide } \\
\text { nanoparticles was studied through scanning electron micrograph and } \\
\text { tested for antibacterial activity against } E \text {. coli and } S \text {. auerus }\end{array}$ & $\begin{array}{l}\text { The optimum condition MgONPs antibacterial activity against } E \text {. coli and } \\
\text { S. auerus was improved. Magnesium oxide nanoparticles could serve as } \\
\text { an alternative to the most commonly used antibiotics used due to their } \\
\text { good antibacterial properties }\end{array}$ \\
\hline 25. & $\begin{array}{l}\text { Melo M. A et al. }{ }^{40} \text { in } \\
2014\end{array}$ & In vitro study & $\begin{array}{l}\text { Dimethylaminododecyl methacrylate (DMADDM) synthesized antibacterial } \\
\text { monomer, was incorporated into orthodontic cement at } 0 \%, 1.5 \%, 3 \% \\
\text { and } 5 \% \text { mass fractions and then the bond strength of brackets to enamel } \\
\text { was measured. A microcosm biofilm using human saliva are representative } \\
\text { of the microbial consortium and complex communities that colonize the } \\
\text { oral cavity was used to measure metabolic activity, lactic acid production, } \\
\text { and colony - forming units. }\end{array}$ & $\begin{array}{l}\text { DMADDM - containing orthodontic bracket cement possessed a } \\
\text { strong antimicrobial activity when incorporating } 3 \% \text { of } \\
\text { DMADDM. The anti-biofilm potency increased with increasing } \\
\text { the DMADDM mass fraction, the enamel bond strength had a } \\
\text { slight decrease at } 5 \% \text { DMADDM. }\end{array}$ \\
\hline
\end{tabular}




\begin{tabular}{|c|c|c|c|}
\hline Nano Particles & Size & Properties & Uses \\
\hline $\begin{array}{l}\text { Gold nanoparticles } \\
\text { (AuNps) }\end{array}$ & $\begin{array}{l}\text { Turkevich et al. created AuNps in } \\
1951 \text { of size } 10-20 \mathrm{~nm}^{9} \\
\text { Brust and Schriffin achieved a } \\
\text { breakthrough in AuNp synthesis in } \\
1994 \text { of size from } 1.5-5 \mathrm{~nm}^{10}\end{array}$ & $\begin{array}{l}\text { Excellent Biocompatibility, low toxicity, } \\
\text { optoelectronic properties, } \\
\text { stable, } \\
\text { Imagining and sensing }{ }^{13} \text {, photo thermal } \\
\text { therapy, }{ }^{14} \text { genetic regulation }{ }^{15} \text { drug treatment. }{ }^{12}\end{array}$ & $\begin{array}{l}\text { Microscopic examination of carcinogenic cells }{ }^{13} \\
\text { immunochemical studies for protein identification \& DNA } \\
\text { detection, tissue engineering, }{ }^{2} \text { imaging agents because of its } \\
\text { optical properties, }{ }^{13} \text { fillers in dental nano composite }{ }^{16}\end{array}$ \\
\hline Silver nanoparticles & 1 to $100 \mathrm{~nm}^{17}$ & $\begin{array}{l}\text { Excellent Biocompatible, anti-inflammatory, } \\
\text { antioxidant, antimicrobial, bactericidal } \\
\text { properties, anticancer, biosubstances }{ }^{15}\end{array}$ & $\begin{array}{l}\text { Effective anti - tumour drug delivery system, },^{18} \text { for its } \\
\text { antimicrobial properties used in treatment of syphilis in } \\
\text { twentieth century, },^{19} \text { used in dentistry in cements and resins, } \\
\text { coated brackets, bands and wires. }{ }^{2}\end{array}$ \\
\hline Titanium nanoparticles & Less than $100 \mathrm{~nm}$ & $\begin{array}{l}\text { Biocompatible, corrosion resistant, effective } \\
\text { photocatalytic activity, low toxicity, high } \\
\text { stability, }{ }^{20,21} \text { antimicrobial properties and } \\
\text { physiochemical properties. }{ }^{22}\end{array}$ & $\begin{array}{c}\text { Used in orthodontics material due to its anticorrosion } \\
\text { properties. }\end{array}$ \\
\hline $\begin{array}{l}\text { Fullerene like tungsten sulfide } \\
\text { nanoparticles } \\
\left(\mathrm{IF}-\mathrm{WS}_{2}\right)\end{array}$ & $\begin{array}{l}\text { Was first time described in } 1992, \\
\quad \text { varies in size } 20-200 \mathrm{~nm}^{23}\end{array}$ & $\begin{array}{c}\text { Solid lubricant with reduced friction and wear } \\
\text { properties }{ }^{24-26}\end{array}$ & $\begin{array}{l}\text { Coated on orthodontic archwire because of their reduced } \\
\text { frictional properties. }\end{array}$ \\
\hline Chitosan nanoparticles & $200 \mathrm{~nm}$ & $\begin{array}{l}\text { Biodegradable, non-toxic, non - antigenic, strong } \\
\text { anti-microbial properties }{ }^{27}\end{array}$ & Added in nano - composite ${ }^{20,28}$ and dentifrice..$^{27}$ \\
\hline Fluoride releasing nanoparticles & $\begin{array}{l}\text { hexagonal and triangular single } \\
\text { crystals vary in size of } 25-350 \mathrm{~nm}\end{array}$ & Anticariogenic properties ${ }^{29}$ & $\begin{array}{l}\text { Fluoride releasing glass ionomer, resin - modified glass } \\
\text { ionomer cements, polyacid modified composites } \\
\text { (compomer), and composite }\end{array}$ \\
\hline Hydroxyapatite nanoparticles & Sizes varies between 50 and $1000 \mathrm{~nm}$ & $\begin{array}{l}\text { Biocompatible and bioactive material, }, 2,31,32 \text { anti - } \\
\text { cariogenic properties. }{ }^{31} \text { antimicrobial } \\
\text { properties. } .^{33}\end{array}$ & $\begin{array}{c}\text { Incorporated in glass ionomer cement, }{ }^{31} \text { orthodontic } \\
\text { adhesives }{ }^{32,33}\end{array}$ \\
\hline Zinc nanoparticles & $30-150 \mathrm{~nm}$ & $\begin{array}{c}\text { Anti - bacterial, antifungal and UV filtering } \\
\text { properties. Low toxicity and good } \\
\text { biocompatibility2,34,10 reduced frictional } \\
\text { properties. }\end{array}$ & $\begin{array}{c}\text { Coated on the orthodontic brackets }{ }^{34} \text {, archwire, }{ }^{35,36} \text { and } \\
\text { adhesives. } .^{10,28}\end{array}$ \\
\hline Copper nanoparticles & 1 to $100 \mathrm{~nm}$ & $\begin{array}{l}\text { Exceptional tensile strength, elastic modulus, } \\
\text { electrical and thermal conductivity, and unique } \\
\text { electronic, magnetic and optical properties. } \\
\text { Antibacterial and antifungal properties } 2,37,38\end{array}$ & Incorporated in orthodontic adhesives ${ }^{37,38}$ \\
\hline Magnesium nanoparticles & $20-60 \mathrm{~nm}$ & $\begin{array}{c}\text { Improves bone regeneration, antibacterial and } \\
\text { antimicrobial properties }{ }^{37,39}\end{array}$ & Incorporated in mini-implants, served as antibiotic ${ }^{39}$ \\
\hline $\begin{array}{l}\text { Quaternary ammonia } \\
\text { nanoparticles }\end{array}$ & $100 \mathrm{~nm}$ & Antimicrobial and antibacterial properties & $\begin{array}{c}\text { Incorporated in dental resin based material }{ }^{2} \text {, orthodontic } \\
\text { cement.40 }\end{array}$ \\
\hline
\end{tabular}

When coating the arch wire, it's important to look at the film's quality, corrosion behaviour, and how many ions are released, because free ions induce cytotoxicity. ${ }^{2}$ By embedding hard alumina nanoparticles in polysulfone, nanoparticles are also employed to make brackets. These brackets are strong, have less friction, and are biocompatible, all while keeping the bracket's transparency ${ }^{1}$. When a nano-coated elastomeric ligature is used, anti-cariogenic fluoride is released. ${ }^{4}$ Nanoparticles are also used on the surface of micro-implants to improve osseointegration and decrease the failure rate of TADs. ${ }^{48}$

\section{CONCLUSIONS}

Despite widespread effectiveness, orthodontic therapy is limited by many issues, including friction, extensive treatment times, and consequences like tissue irritation, tooth decalcification owing to bacterial development, and root resorption. Nanoparticles bond strongly to other materials or each other due to their large surface free energy (agglomeration). The nano - coatings produced are either lubricants to reduce friction or antibacterial to minimize microbial counts and the issues that come with them, including cavities, periodontal illnesses, and decalcification around the bracket. 5 The unique features of silver and gold nanoparticles can be used to give local anaesthetic, diagnose, and treat oral problems. Nanoparticles are employed in orthodontics because of their biocidal, anti-adhesive, and anti-biofilm properties, as well as their demineralization effect and friction reduction.9-15,49,16-19 Based on the coating substance, nanoparticles are biocompatible and less cytotoxic. Friction being the most important in fixed mechanotherapy for alignment and levelling, as well as space closure. Up to $60 \%$ of the force is wasted as friction, reducing the force available for tooth movement and necessitating the application of extra force to counteract the frictional force. Increased friction during orthodontic treatment can cause a variety of issues, including trouble with anchoring management and an increase in the length of orthodontic therapy. Several strategies have been developed to reduce friction and improve both the mechanical and biological properties of orthodontic wires, including changing the bracket design, using various types of alloys, surface treatment or coating of brackets using various techniques and materials, and modifying the surface of both the archwires and brackets. On stainless steel and NiTi wire, nanoparticles such as copper oxide,37 inorganic fullerene - like nanoparticles of tungsten disulphide, ${ }^{48,28}$ and Co + fullerene like WS2 NPs, ${ }^{24}$ silver - coated nanoparticles ${ }^{19}$ and zinc oxide nanoparticles on the orthodontic bracket and an archwire ${ }^{35}$ showed a $50 \%$ reduction in coefficient of friction. During orthodontic treatment, plaque collection on fixed and removable appliances is also a typical issue. Gingivitis, periodontitis, white spot lesions, increased caries risk, halitosis, superimposed infections, TAD failure, and delayed tooth movement are all possible repercussions of bacterial development. Nanoparticles as antibacterial agents can be included or put on bracket surfaces, resin composites, glass ionomer cement, and mini-implants to reduce these issues. ${ }^{5}$ Nanoparticles coated on bracket which showed excellent antibacterial effect and biocompatibility were silver NP, 21,31,40,50 Titanium nitrite, 1 Nitrogen - doped titanium oxide, ${ }^{21,22} \mathrm{CuO} \& \mathrm{ZnO}$ NP. ${ }^{37}$ Carbon nanoparticles were integrated into stainless steel wire. ${ }^{38}$ Silver nanoparticles coated on mini-implants used as temporary anchorage devices have antibacterial properties, and are safe and prevent implant infection. ${ }^{44,51}$ Nano - composite showed a good antibacterial effect when incorporated with ZnO NP and Chitosan NP,20,28 titanium oxide NP,45 nitrogen doped titanium oxide $\mathrm{NP},{ }^{29}$ hydroxyapatite $\mathrm{NP}^{20,32}$ and fluoride 
releasing nano- composite to prevent demineralization. Nanosized fluorapatite (NFA) or fluorohydroxyapatite (NFHA) particles at a concentration of $25 \%, 31,52$ silver nanoparticles, ${ }^{53,54}$ magnesium oxide, 55 and quaternary ammonium nanoparticles have all been used to improve GIC. 40

Nanotechnology is widely used in our day-to-day life including its use in medicine. In $21^{\text {stcentury based on its }}$ economic and scientific potential, nanotechnology holds promise in many areas like advanced diagnostics, targeted drug delivery and biosensors. It has several applications in dentistry as well, from diagnosis of pathological conditions to local anaesthesia, orthodontic tooth movement and periodontics. In the field of orthodontics, nano-coating on the orthodontic archwire, brackets, bands, elastomeric ligatures, orthodontic power chains, mini-implants are used for its reduced friction properties, excellent corrosion resistance, and good antimicrobial property, fluoride- releasing nanofilled composite (FN) reduces the caries lesion development around the brackets and nanoparticles can be used as agents for remineralization of decalcified enamel.

This present reviewed article summarized the most significant innovation of nanotechnology in the field of orthodontics and reviewed the most recent literature comparing with different research studies and focusing the attention on the application of new nanoparticles and their benefits. The nanomaterials have introduced many advantages in the field of orthodontics, especially with improved mechanical and antimicrobial properties. The future in orthodontic treatment will benefit enormously through nanotechnology should all the current attempts succeed in its clinical application at a reasonable cost to the orthodontist and patients.

Financial or other competing interests: None.

Disclosure forms provided by the authors are available with the full text of this article at jemds.com.

\section{REFERENCES}

[1] Kao CT, Ding SJ, Chen YC, et al. The anticorrosion ability of titanium nitride (TiN) plating on an orthodontic metal bracket and its biocompatibility. Journal of Biomedical Materials Research 2002;63(6):786-92.

[2] Batra P, Mushtaq A, Mazumder J, et al. Nanoparticles and their applications in orthodontics. Adv Dent Oral Health 2016;2(2):555584.

[3] Batra P. Applications of nanoparticles in orthodontics. In: Dental applications of nanotechnology. Cham: Springer 2018: p. 81-105.

[4] Govindankutty D. Applications of nanotechnology in orthodontics and its future implications: a review. Int J Appl Dent Sci 2015;1(4):166-71.

[5] Allaker RP. The use of nanoparticles to control oral biofilm formation. Journal of Dental Research 2010;89(11):1175-86.

[6] Patra JK, Das G, Fraceto LF, et al. Nano based drug delivery systems: recent developments and future prospects. Journal of Nanobiotechnology 2018;16:71.

[7] Jeevanandam J, Barhoum A, Chan YS, et al. Review on nanoparticles and nanostructured materials: history, sources, toxicity and regulations. Beilstein Journal of Nanotechnology 2018;9(1):1050-74.

[8] Buzea C, Pacheco II, Robbie K. Nanomaterials and nanoparticles: sources and toxicity. Biointerphases 2007;2(4):MR17-71.

[9] Turkevich J, Stevenson PC, Hillier J. A study of the nucleation and growth processes in the synthesis of colloidal gold. Discussions of the Faraday Society. 1951;11:55-75.

[10] Brust M, Walker M, Bethell D, et al. Synthesis of thiol derivatised gold nanoparticles in a two - phase liquidliquid system. Journal of the Chemical Society, Chemical Communications 1994;(7):801-2.

[11] Yeh YC, Creran B, Rotello VM. Gold nanoparticles: preparation, properties and applications in bionanotechnology. Nanoscale 2012;4(6):1871-80.

[12] Dykman L, Khlebtsov N. Gold nanoparticles in biomedical applications: recent advances and perspectives. Chemical Society Reviews 2012;41(6):2256-82.

[13] Katas H, Moden NZ, Lim CS, et al. Biosynthesis and potential applications of silver and gold nanoparticles and their chitosan - based nanocomposites in nanomedicine. Journal of Nanotechnology 2018;2018:4290705.

[14] Van de Broek B, Devoogdt N, D’Hollander A, et al. Specific cell targeting with nanobody conjugated branched gold nanoparticles for photothermal therapy. ACS Nano 2011;5(6):4319-28.

[15] McMahon KM, Mutharasan RK, Tripathy S, et al. Biomimetic high density lipoprotein nanoparticles for nucleic acid delivery. Nano Letters 2011;11(3):1208-14.

[16] Al-Nafori MK, Elshal MG, Refai WM. The effect of incorporating gold and silver nanoparticles in orthodontic adhesive system on bond strength of orthodontic bracket. EC Dental Science 2017;11(4):11931.

[17] Syafiuddin A, Salim MR, Kueh BHA, et al. A review of silver nanoparticles: research trends, global consumption, synthesis, properties and future challenges. Journal of the Chinese Chemical Society 2017;64(7):732-56.

[18] Burdușel AC, Gherasim 0, Grumezescu AM, et al. Biomedical applications of silver nanoparticles: an up - to - date overview. Nanomaterials 2018;8(9):681.

[19] Shah PK, Sharma P, Goje SK. Comparative evaluation of frictional resistance of silver - coated stainless steel wires with uncoated stainless steel wires: an In vitro study. Contemporary Clinical Dentistry 2018;9(Suppl 2):S331S6.

[20] Sodagar A, Bahador A, Khalil S, et al. The effect of TiO2 and SiO2 nanoparticles on flexural strength of poly (methyl methacrylate) acrylic resins. Journal of Prosthodontic Research 2013;57(1):15-9.

[21] Salehi P, Babanouri N, Roein-Peikar M, et al. Long - term antimicrobial assessment of orthodontic brackets coated with nitrogen - doped titanium dioxide against Streptococcus mutans. Progress in Orthodontics 2018;19(1):35.

[22] Cao B, Wang Y, Li N, et al. Preparation of an orthodontic bracket coated with an nitrogen - doped TiO2 - xNy thin film and examination of its antimicrobial performance. Dental Materials Journal 2013;32(2):311-6. 
[23] Tenne AR, Margulis L, Genut ME, et al. Polyhedral and cylindrical structures of tungsten disulphide. Nature 1992;360(6403):444-6.

[24] Friedman H, Eidelman O, Feldman Y, et al. Fabrication of self - lubricating cobalt coatings on metal surfaces. Nanotechnology 2007;18(11):115703.

[25] Redlich M, Katz A, Rapoport L, et al. Improved orthodontic stainless steel wires coated with inorganic fullerene - like nanoparticles of WS2 impregnated in electroless nickelphosphorous film. Dental Materials 2008;24(12):1640-6.

[26] Samorodnitzky-Naveh GR, Redlich M, Rapoport L, et al. Inorganic fullerene - like tungsten disulfide nanocoating for friction reduction of nickel-titanium alloys. Nanomedicine 2009;4(8):943-50.

[27] Uysal T, Akkurt MD, Amasyali M, et al. Does a chitosan containing dentifrice prevent demineralization around orthodontic brackets? The Angle Orthodontist 2011;81(2):319-25.

[28] Mirhashemi AH, Bahador A, Kassaee MZ, et al. Antimicrobial effect of nano - zinc oxide and nano chitosan particles in dental composite used in orthodontics. Journal of Medical Bacteriology 2013;2(3,4):1-10.

[29] Zane A, Zuo R, Villamena FA, et al. Biocompatibility and antibacterial activity of nitrogen - doped titanium dioxide nanoparticles for use in dental resin formulations. International Journal of Nanomedicine 2016;11:6459. 6470.

[30] Melo MA, Morais WA, Passos VF, et al. Fluoride releasing and enamel demineralization around orthodontic brackets by fluoride - releasing composite containing nanoparticles. Clinical Oral Investigations 2014;18(4):1343-50.

[31] Enan ET, Hammad SM. Microleakage under orthodontic bands cemented with nano - hydroxyapatite - modified glass ionomer: an in vivo study. The Angle Orthodontist 2013;83(6):981-6.

[32] Chung JH, Kim YK, Kim KH, et al. Synthesis, characterization, biocompatibility of hydroxyapatitenatural polymers nanocomposites for dentistry applications. Artificial Cells, Nanomedicine and Biotechnology 2016;44(1):277-84.

[33] Akhavan A, Sodagar A, Mojtahedzadeh F, et al. Investigating the effect of incorporating nanosilver / nanohydroxyapatite particles on the shear bond strength of orthodontic adhesives. Acta Odontologica Scandinavica 2013;71(5):1038-42.

[34] Ramazanzadeh B, Jahanbin A, Yaghoubi $M$, et al. Comparison of antibacterial effects of $\mathrm{ZnO}$ and $\mathrm{CuO}$ nanoparticles coated brackets against Streptococcus mutans. Journal of Dentistry 2015;16(3):200-5.

[35] Kachoei M, Eskandarinejad F, Divband B, et al. The effect of zinc oxide nanoparticles deposition for friction reduction on orthodontic wires. Dental Research Journal 2013;10(4):499-505.

[36] Metin-Gürsoy G, Taner L, Akca G. Nanosilver coated orthodontic brackets: in vivo antibacterial properties and ion release. European Journal of Orthodontics 2017;39(1):9-16.

[37] Argueta-Figueroa L, Scougall-Vilchis RJ, Morales-Luckie RA, et al. An evaluation of the antibacterial properties and shear bond strength of copper nanoparticles as nanofiller in orthodontic adhesive. Australian Orthodontic Journal 2015;31(1):42-8.

[38] Toodehzaeim MH, Zandi H, Meshkani H, et al. The effect of $\mathrm{CuO}$ nanoparticles on antimicrobial effects and shear bond strength of orthodontic adhesives. Journal of Dentistry 2018;19(1):1-5.

[39] Khanna P, Kaur A, Goyal D. Algae-based metallic nanoparticles: synthesis, characterization and applications. Journal of Microbiological Methods 2019;163:105656.

[40] Melo MA, Wu J, Weir MD, et al. Novel antibacterial orthodontic cement containing quaternary ammonium monomer dimethylaminododecyl methacrylate. Journal of Dentistry 2014;42(9):1193-201.

[41] Metin-Gürsoy G, Taner L, Barış E. Biocompatibility of nanosilver - coated orthodontic brackets: an in vivo study. Progress in Orthodontics 2016;17(1):39.

[42] Mhaske AR, Shetty PC, Bhat NS, et al. Antiadherent and antibacterial properties of stainless steel and $\mathrm{NiTi}$ orthodontic wires coated with silver against Lactobacillus acidophilus-an in vitro study. Progress in Orthodontics 2015;16:40.

[43] Hernández-Gómora AE, Lara-Carrillo E, Robles-Navarro JB, et al. Biosynthesis of silver nanoparticles on orthodontic elastomeric modules: evaluation of mechanical and antibacterial properties. Molecules 2017;22(9):1407.

[44] Venugopal A, Muthuchamy N, Tejani H, et al. Incorporation of silver nanoparticles on the surface of orthodontic microimplants to achieve antimicrobial properties. The Korean Journal of Orthodontics 2017;47(1):3-10.

[45] Poosti M, Ramazanzadeh B, Zebarjad M, et al. Shear bond strength and antibacterial effects of orthodontic composite containing $\mathrm{TiO} 2$ nanoparticles. European Journal of Orthodontics 2013;35(5):676-9.

[46] Cibim DD, Saito MT, Giovani PA, et al. Novel Nanotechnology of TiO2 improves physical - chemical and biological properties of glass ionomer cement. International Journal of Biomaterials 2017;2017:7123919.

[47] Behroozian A, Kachoei M, Khatamian M, et al. The effect of $\mathrm{ZnO}$ nanoparticle coating on the frictional resistance between orthodontic wires and ceramic brackets. Journal of Dental Research, Dental Clinics, Dental Prospects 2016;10(2):106-11.

[48] Imani MM, Safaei M. Optimized synthesis of magnesium oxide nanoparticles as bactericidal agents. Journal of Nanotechnology 2019;2019:6063832.

[49] Brown SD, Nativo P, Smith JA, et al. Gold nanoparticles for the improved anticancer drug delivery of the active component of oxaliplatin. Journal of the American Chemical Society 2010;132(13):4678-84.

[50] Espinosa-Cristóbal LF, López-Ruiz N, Cabada-Tarín D, et al. Antiadherence and antimicrobial properties of silver nanoparticles against Streptococcus mutans on brackets and wires used for orthodontic treatments. Journal of Nanomaterials 2018;2018:9248527.

[51] Pauksch L, Hartmann S, Rohnke M, et al. Biocompatibility of silver nanoparticles and silver ions in primary human mesenchymal stem cells and osteoblasts. Acta Biomaterialia 2014;10(1):439-49. 
[52] Lin J, Zhu J, Gu X, et al. Effects of incorporation of nano fluorapatite or nano - fluorohydroxyapatite on a resin modified glass ionomer cement. Acta Biomaterialia 2011;7(3):1346-53.

[53] Ahn SJ, Lee SJ, Kook JK, et al. Experimental antimicrobial orthodontic adhesives using nanofillers and silver nanoparticles. Dental Materials 2009;25(2):206-13.
[54] Moreira DM, Oei J, Rawls HR, et al. A novel antimicrobial orthodontic band cement with in situ-generated silver nanoparticles. The Angle Orthodontist 2015;85(2):17583.

[55] Issa B, Obaidat IM, Albiss BA, et al. Magnetic nanoparticles: surface effects and properties related to biomedicine applications. International Journal of Molecular Sciences 2013;14(11):21266-305. 